a benne lévő utalások alapján ez is inkább csak a század legvégére tehető, mintsem a címben is szereplő 17. századra. A pontosabb datálás miatt is fontos lett volna kideríteni, hogy ki volt az a bécsi jezsuita, aki német nyelven kétségbe vonta a héber biblia hitelességét, és akire Seidel két helyen is utalt. Ráadásul, ezekből az utalásokból (akárcsak az 1590-es prágai könyv említéséből) kiindulva talán Seidel életének későbbi éveire vonatkozóan is további információkhoz juthatnánk. Seidel mindenképp megérdemli figyelmünket és csak remélhetjük, hogy e kötet nem a rá vonatkozó kutatások lezárását, hanem további kutatások nyitányát jelenti.

Almási GÁBor

\section{Kovács Eszter, Iszlámismeret Csehország- ban a 16-17. század fordulóján, Budapest, OSZK, PPKE, 2017.}

A Pázmány Péter Katolikus Egyetem és az Országos Széchényi Könyvtár kiadásában látott napvilágot 2017-ben Kovács Eszter legújabb kötete, amely a cseh Turcica-irodalom egy különleges müfajának bemutatására vállalkozott. A Pázmány Péter Katolikus Egyetemen Öze Sándor vezetésével már évek óta kutatócsoport foglalkozik az iszlám kultúrával kapcsolatba kerülő keresztény népek irodalmával, és a „Felekezet és identitás fogalmai és kérdései a kollektív szimbólumok tükrében az oszmánkeresztény határrégióban a 15-19. században" projekt keretében már meg is jelent egy kiadvány (BALÁzs József, SzUromi Kristóf, $A z e u$ rópai iszlámkép Theodor Bibliander gyüjteményének tükrében, Bp., Pázmány Péter Katolikus Egyetem Történettudományi Intézet, 2016). A most ismertetett kötet is e kutatási program eredményeképpen jött létre, és a középpontjában két cseh nyelvü, iszlámról szóló munka, pontosabban azok magyar nyelvü fordítása áll. Az egyik szöveg a 16. századi utraquista lelkész, Bartoloměj Dvorský Proti Alchoranu $[\mathrm{Az}$ Alkorán ellen] címü munkája, a másik a 1617. században müködő, és az 1618-as cseh felkelésben való részvétele miatt 1621-ben kivégzett csehtestvér, Václav Budovec széles körben ismert Korán-polemikája, az Antialkorán.
A könyv két, jól elkülöníthető szerkezeti egységre osztható: egy hosszabb lélegzetü bevezető tanulmányra és Bartoloměj Dvorský, illetve Václav Budovec müveiből kiemelt szövegrészek fordítására.

Kovács Eszter A török és az iszlám a 16. századi cseh irodalomban címü terjedelmes és alapos tanulmányában (11-71) részletesen bemutatja a kiadvány második részében szereplő műveket. Mielőtt azonban a szerző a konkrét munkákra rátérne, hangsúlyozza, hogy a cseh korona országainak közvéleménye számára leginkább a mohácsi csatavesztést követően vált aktuális problémává az oszmán-török hódítás. A 16. század első felében kezdtek megjelenni a törökökkel foglalkozó művek, többnyire röpiratok, abból a célból, hogy a törökveszélyt még inkább tudatosítsák a Csehország, Morvaország és Szilézia lakosságában. Jellegükből fakadóan azonban e munkák nagy része mára már elveszett. A törökök vallását ebben az időben Csehországban még alig ismerték, ezért 16. század közepére a cseh egyházi értelmiség szükségét érezte a muszlim hit megismertetésének és cáfolatának.

Ezután tér rá Kovács Dvorský életútjának bemutatására és munkájának, az első nagyobb terjedelmü cseh nyelvü, 1542-ben megjelent Koráncáfolatnak, a Proti Alchoranunak az elemzésére (15-24). A szerző jó érzékkel nyúl a témához, hiszen tömören, de felettébb informatívan mutatja be Dvorský múvének tartalmát és szemléletét. Dvorský úgy érezte, a felületes szemlélő számára az iszlám könnyen azonosítható a kereszténységgel, ezért munkájában a két vallás közti különbségeket hangsúlyozza. Külön kiemeli azokat a hittételeket (áteredő bün, Jézus Krisztus istensége, szentháromság, Oltáriszentség), amelyeket az iszlám elutasít. Mivel Dvorský szerint a muszlimok hite az egyszerüségénél és a kereszténységhez füződő bizonyos hasonlósága folytán vonzó lehet, mindenekelőtt a fenti hittételeket kívánja megmagyarázni az olvasók számára. Külön kitér a muszlimok és keresztények erkölcsbeli és életmódbeli eltéréseire is. Igen érdekes Dvorský cáfolata a többnejüségről és a borivás tilalmáról, amely szövegrészek magyarul is olvashatók a válogatott szemelvények között. 
Nem hiányozhat a Proti Alchoranuból sem a korban a keresztény szerzők közt szinte mindig felbukkanó kérdésfeltevés, hogy ha a kereszténység az igaz vallás, akkor Isten miért engedi, hogy a törökök győzzenek? Dvorský erre a műfaj más képviselőivel megegyező választ adja, vagyis hogy a keresztények bünei okozzák a török hadi sikereit. Mivel a török hódítást a keresztények erkölcsi züllése miatti isteni büntetésnek tekintette, a megoldást a kor közgondolkodásának megfelelően ő is a keresztények erkölcsi megújulásában látta.

Kovács Eszter az elemzésében arra is felhívja a figyelmet, hogy Dvorský a törökök életmódját és a Koránt csak közvetett forrásokból ismeri, mivel döntően a neves teológus és filológus szerzetes, Karthauzi Dénes Contra perfidiam Mahometi és Dialogus disputationis inter Christianum et Sarracenum címủ müveire támaszkodott.

Kovács ezt követően tér rá Budovec életét és munkáját tárgyaló, szerkezetileg igen jól felépített bemutatására. Az előzőnél jóval hoszszabb elemzés (25-71) oka nyilvánvalóan az, hogy Budovec Antialkorán címủ múve nagyobb terjedelmü és Dvorský Proti Alchora$n u$ jához viszonyítva a szakirodalma is bővebb. Kovács először a mű keletkezését, célját és felépítését tárgyalja.

Budovec múve kétségtelenül a kora újkori cseh irodalom legismertebb és legalaposabb koránpolemikája, amelynek első változata már 1593ban elkészült, de a cenzúra miatt csak 1614-ben jelenhetett meg nyomtatásban. Budovec alapos kutatómunkát követően vetette papírra az $A n$ tialkoránt. Dvorskýval ellentétben ő valóban használta forrásként a Koránt, pontosabban annak Theodor Bibliander által kiadott latin nyelvü változatát. De ezen túlmenően Konstantinápolyban is járt, ahol a könyvekből szerzett ismereteit kiegészítette személyes tapasztalataival, és muszlimokkal, főleg az iszlámra áttért keresztényekkel folytatott hitvitái tanulságaival.

A muszlim hit tévedéseinek bemutatásán túlmenően Budovec fö célja, hogy a törökök ellen harcoló keresztény vitézeknek útmutatást adjon, hogy miként harcoljanak úgy, hogy a saját üdvösségük ne kerüljön veszélybe. Budovec ugyanis valódi veszélynek tartja, hogy az iszlámmal kap- csolatba kerülő keresztények esetleg elhagyják a keresztény hitüket a muszlim vallásért.

Az Antialkorán keletkezésének és céljának tárgyalása után Kovács lényegében részletesen leírja a mü teljes tartalmát, amiből nyilvánvalóvá válik, hogy ez mindenekelőtt egy hitvédő irat. Ennek fényében különösen érdekes, hogy a tanulmány szerzője Budovec szemléletét összekapcsolja a korabeli apokaliptikus világszemlélettel. Kovács meggyőzően bizonyítja, hogy Budovec az Oszmán Birodalom terjeszkedését a végidők jeleként fogja fel, és ezzel lényegében apokaliptikus felfogása a huszita és lutherimelanchtoni hagyományokra épül.

Nagy erénye továbbá az elemzésnek, hogy a szerző mindig visszautal Dvorskýra, és kihangsúlyozza, hogy miben egyezik meg, és miben különbözik a két mü, és a bevezető tanulmány végén még össze is foglalja ez irányú megfigyeléseit. Eszerint mindkét munka Korán-polemika, és mindkét esetben a szerzők fó célja, hogy felkészítsék a keresztényeket, hogy a fegyveres harc mellett, hanem hogy lelki síkon is háborút fognak viselni. Ez utóbbiból szerintük a keresztények csak úgy kerülhetnek ki győztesen, ha lelkileg megújulnak és saját vallásukban jobban elmélyednek. Kétségtelen, hogy Dvorský és Budovec a huszitizmus eltérő irányzatához tartoztak, de mindketten a keresztények összefogását szorgalmazzák. Ugyanakkor Dvorský és Budovec egyaránt határozottan veszélyesnek ítélik a szentháromságtagadókat (unitáriusok, szociniánusok), mintegy belső törököknek tartva őket. Azon túlmenően, hogy Budovec jóval alaposabb kutatómunkával írta meg a művét, és szélesebb forrásbázisának, valamint személyes tapasztalatainak köszönhetően pontosabb az iszlámismerete, markáns különbség a két munka között leginkább a megformálásban van. Dvorský stílusa egyszerú, a szókincs szükös, nyilvánvalóan a törekedett arra, hogy írása közérthető legyen. Ezzel szemben Budovec igazi barokk remekmüvet vetett papírra, bonyolult többszörösen összetett körmondatokkal, változatos és gazdag szókinccsel.

A remek elemzésben mindössze két dolog zavarhatja az olvasót. Az egyik, hogy Dvorskýval kapcsolatban mindig kiemeli a szerző, hogy 
az utraquista egyházhoz tartozott, de csupán a 18. lábjegyzetben utalja az olvasót a „Huszita elemek a Proti-Alchoranu-ban" fejezethez, ahol a föszövegben magyarázza meg, hogy mit is kell értenünk pontosan az utraquista egyház alatt. A korszak kutatói számára lehet, hogy ez nyilvánvaló, de sokkal szerencsésebb lett volna a kifejezés első előfordulásakor lábjegyzetben megmagyarázni, hiszen a kötet a történelem iránt érdeklődő nem szakmai közönség figyelmére is számot tarthat. A másik szintén a lábjegyzetekhez köthető probléma, hogy az elemzés során a szerző a hivatkozásokban mindig az eredeti cseh nyelvü munkák locusait adja meg. Ez önmagában természetesen nem baj, de olvasóbarátabb lett volna, hogy ha mellette zárójelben a kötetben található fordítások oldalszámait is odaírta volna a szerző vagy a szerkesztő.

A bevezető tanulmányt követően érkezünk a második, Válogatott szövegek címet viselö szerkezeti egységhez (73-234), vagyis a Proti Alchoranu (75-113) és az Antialkorán (115234) fontosabb részeinek fordításához. A cseh szövegek fordítását a bevezető tanulmány szerzője, Kovács Eszter, valamint Boros Attila készítette. A fordításokról általánosságban elmondható, hogy gördülékenyek, világosak és könynyen olvashatók. Több fordító esetén gyakran előfordulhat, hogy a szöveg stílusán érződik, hogy nem egy ember készítette, de itt az esetleges különbségeket nagyon jól sikerült elsimítani, ami nyilvánvalóan a fordítók mellett a lektorok munkáját is dicséri.

Mindkét forráshoz gazdag és pontos hivatkozási apparátus tartozik, amelyben nem csak a bibliai és Korán-idézetek pontos helyei vannak megjelölve, hanem olykor hosszabb müvelődéstörténeti információkat is tartalmaznak, ezzel pedig komoly segítséget nyújtanak az olvasónak a szövegek pontos megértéséhez. Különösen helyes eljárás, hogy a jegyzetek készítője, Kovács Eszter a szerzők tévedéseire is minden alkalommal felhívja a figyelmet.

Egy jó fordítás elkészítése mindig nehéz feladat, főleg, ha ilyen nagymennyiségü szöveget kell átültetni magyarra. A válogatás elve teljes mértékben elfogadható, mindazonáltal az amúgy kiváló kötet értékét is nagymértékben növelte volna, ha legalább Dvorský munkájának teljes magyar fordítása belekerül volna a kiadványba.

Még néhány mondatban szólnom kell a könyv fizikai megjelenéséről. Szemmel látható, hogy tartalom mellett a készítők erre is különös gondot fordítottak. A tördelésre nem lehet panasz, a szép papírra nyomott szöveget igen kellemes olvasni. De mindezen felül különösen szépek az eredeti müvekből átvett fametszetek, amelyeknek fontos szerepük van, hiszen Kovács Eszter tanulmányában nagy hangsúlyt kapnak az egyes ábrázolások elemzései.

Összefoglalva az mondhatom, hogy Kovács Eszter kötete formailag és tartalmilag egyaránt igényes munka. Nemcsak a korszakkal foglalkozó történészeknek, hanem a téma iránt érdeklődő nem szakmabeli olvasóknak is ajánlom. E minőségi munka fényében pedig a kutatási program tervezett következő köteteire is pozitív várakozással tekinthetünk.

SZEBELÉDi Zsolt

Die Hungarica-Sammlung der Franckeschen Stiftungen zu Halle, hrsg. v. Brigitte Klosterberg und István Monok, Alte Drucke 1495-1800, Bd. I. A-O, Bd. II. P-Z, bearbeitet von Attila Verók, Budapest, MTA Könyvtár és Információs Központ, 2017 (Adattár XVI-XVIII. századi szellemi mozgalmaink történetéhez $=$ Materialien zur Geschichte der Geistesströmungen des 16.-18. Jahrhunderts in Ungarn, 40/1-2). 1235 p.

A wolfenbütteli Herzog August Bibliothek és a Hallében található Franckesche Stiftungen könyvtára a kora újkorral foglalkozó magyar művelődés-, irodalom- és könyvtörténészek számára sok vonatkozásban meghatározó. Ebbe a két intézménybe - amely könyvmúzeum és nemzetközi kutatóközpont is egyben - évtizedek óta úgy özönlenek a hazai kutatók, mint ahogyan a régi századok peregrinusai látogatták a németországi egyetemeket. Wolfenbüttel esetében ez már a 20. század 70-es, 80-a éveiben elkezdődött, Halle iránt pedig az utóbbi két évtizedben növekedett meg igazán a magyar szakemberek érdeklődése. A gazdag forrásanyag, 